\title{
Assessing the importance of protein interactions and hydration level on protein enriched gluten-free breads. A novel approach
}

\author{
Ángela Bravo-Núñez*, Marta Sahagún, Manuel Gómez
}

Food Technology Area. College of Agricultural Engineering. University of Valladolid, 34071 Palencia, Spain.

*Corresponding author e-mail: angela.bravo@uva.es

\begin{abstract}
The effect of starch substitution by $30 \%$ of different mixtures of egg white and pea proteins (100:0; $75: 25 ; 50: 50 ; 25: 75 ; 0: 100)$ was studied. The effect of hydration levels on specific volume was determined in order to later study the physical characteristics of different protein-enriched breads with an adjusted hydration level to achieve a specific volume similar to that of commercial wheat breads $\left(5.5 \pm 0.5 \mathrm{~cm}^{3} / \mathrm{g}\right)$. Hydration level needs to achieve this specific volume increased when increasing pea protein ratio. Control batter presented the highest elastic modulus, followed by the batter enriched with pea protein. Elastic modulus decreased progressively when increasing egg protein content. Same trend was observed for the viscous modulus. Differently, hardness was increased by the presence of egg protein, while decreased with the presence of pea protein. Breads with the same amount of both proteins showed no significant differences, compared to the control hardness. Regarding crumb structure, egg protein generated a uniform structure of small air bubbles that opened progressively when the proportion of pea protein was increased, until the same levels of both proteins were added, closing again with a higher pea protein content, but was not as close as when egg protein only was added.
\end{abstract}

Key words: Protein synergy, gluten-free, bread, hydration, volume 


\section{Introduction}

There has been increasing interest in the protein enrichment of bakery goods among both the industry and scientific community in recent years. Some of the reasons for this trend are the specific needs of certain population groups that require a higher protein intake such as athletes, who have a recommended daily protein intake of $1.2 \_2 \mathrm{~g} / \mathrm{kg}$ body weight (Thomas, Erdman, \& Burke, 2016), in contrast to the $0.83 \mathrm{~g} / \mathrm{kg}$ body weight recommended for an average adult. In addition, some studies suggest that a protein intake that is higher than current recommendations may be beneficial for elderly people (Nowson \& O’Connell, 2015), and when the recommended protein intake is not achieved through a regular diet, oral supplements are often prescribed (Nieuwenhuizen, Weenen, Rigby, \& Hetherington, 2010). Recently, it has been proven that protein-enriched familiar foods increase the protein intake of hospitalised older adults, compared to a group that followed an energy- and protein-rich hospital menu with supplements (Beelen et al., 2018). This reaffirms the need for more scientific research in order to develop protein-enriched products and satisfy the demands of potential consumers. Gluten-free breads contain a lower protein content than those made with wheat (Miranda, Lasa, Bustamante, Churruca, \& Simon, 2014), and therefore the protein enrichment of gluten-free breads is an interesting option, as consumers of gluten-free breads are also demanding products of better nutritional quality.

Several studies have looked at the protein enrichment of gluten-free breads, but usually contain a protein addition of at most $10 \%$, with the exception of some studies that have added up to $15 \%$ by means of egg white protein (Crockett, Ie, \& Vodovotz, 2011; Han et al., 2019), 15-30\% of dairy

proteins (Krupa-Kozak, Baczek, \& Rosell, 2013), and Sahagún \& Gómez (2018), that studied the influence of the substitution of $30 \%$ of starch with vegetal or animal proteins.

In addition, little attention has been given to the effect of hydration levels in the characteristics of gluten-free breads; this could be due to the fact that no validated equipment to determine the optimal hydration levels of gluten-free breads, similar to the farinograph for wheat breads, exists. There have been some attempts to adjust the hydration levels of gluten-free breads to achieve a constant consistency (e.g. Martínez, Oliete, Román, \& Gómez (2014) or Ziobro, Juszczak, Witczak, \& Korus (2016)). In other cases, hydration level of gluten-free breads was adjusted depending on the water-binding capacity of some of the ingredients (e.g. Espinosa-Ramírez, 
Garzon, Serna-Saldivar, \& Rosell (2018)). These attempts have focused more on the effect of hydration levels on batters than on the parameters of the final breads. Other studies (e.g. Crockett et al., (2011)) have adjusted the hydration level, but have not taken into account the specific parameters of the dough or breads, making their adjustment hard to extrapolate. Only Ronda, Perez-Quirce, Lazaridou, \& Biliaderis (2015), in their study of $\beta$-glucan concentrates, have adjusted hydration levels to optimise the specific volume, which is known to be an important quality parameter for consumers, as have Sahagún \& Gómez (2018) in their investigation into the protein enrichment of gluten-free breads. In both studies, the hydration level was adjusted to achieve the maximum specific volume possible for each bread, after which the physical characteristics of the optimised breads were measured. Although these two studies have examined the influence of hydration levels not only on batter rheology but also on the characteristics of bread, it is also important to study the characteristics of gluten-free breads with specific volumes similar to those of commercial wheat breads (between 4.5 and $5.5 \mathrm{~cm}^{3} / \mathrm{g}$ ) because this is one potential way of making them more appealing to potential consumers.

When Sahagún \& Gómez (2018) modelled the influence of different hydration levels on specific volumes of protein-enriched gluten-free breads, they observed an antagonist effects on the characteristics of gluten-free breads, when the enrichment was done with vegetal or animal proteins. This being so, enriching gluten-free breads with protein mixtures of animal and vegetal sources could balance the effect of each protein, and lead to breads that are more similar to nonenriched breads. In addition, unifying the specific volume makes it possible to study textural differences beyond the effects of specific volumes on this parameter. To the best of our knowledge, no studies have yet followed this approach.

In this study, the hydration levels of gluten-free batters with a substitution of 30\% of maize starch with mixtures of egg white and pea proteins $(100: 0 ; 75: 25 ; 50: 50 ; 25: 75 ; 0: 100)$ were optimised to achieve a constant volume of $5.5 \pm 0.5 \mathrm{~cm}^{3} / \mathrm{g}$ for all breads. To achieve a constant specific volume, the hydration level of each batter was optimised by modelling the influence of different batter hydration levels on the specific volumes of breads, after which the rheological and physical characteristics (texture and weight loss) of the optimised batters and breads were studied. 


\section{Materials and methods}

\subsection{Materials}

Maize starch (7.83\% moisture, 0.76 water binding capacity, Tereos, Zaragoza, Spain), pea protein (Nutralys F85 M; 78.13\% protein, 6.16\% moisture, 38\% solubility, 5.40 water binding capacity, Roquette, Lesterm, France), and egg white protein powder (81.66\% protein, $6.18 \%$ moisture, 100\% solubility, 0.00 water binding capacity; EPS S.P.A., Occhiobello, Italy) were used. Protein content information was provided by the suppliers. Moisture and water-binding capacity were measured using AACC methods 44-16.01 and 56.30, respectively (AACC, 2012). Protein solubility was evaluated by the Quick Start ${ }^{\mathrm{TM}}$ Bradford Protein Assay (Bio Rad, Hercules, California, USA).

Sugar (AB Azucarera Iberica, Valladolid, Spain), salt (Disal, Unión Salinera de España S.A, Madrid, Spain), refined sunflower oil (Langosta, F. Faiges, S.L., Daimiel, Ciudad Real, Spain), hydroxypropyl methylcellulose K4M (Rettenmaier \& Sohne, Rosenberg, Germany), and instant dry baker's yeast (Dosu Maya Mayacilik A.Ş, Istanbul, Turkey) were also used.

\subsection{Methods}

\subsubsection{Bread formulation}

The bread formulations are shown in Table 1. The water content was dependent on the desired hydration level, as explained in section 2.2.2.

Yeast was mixed with the water for its hydration. All other ingredients were mixed for $1 \mathrm{~min}$ at speed 1 using a KitchenAid Professional mixer (Kitchen Aid, St. Joseph, Michigan, USA) with a dough hook $(\mathrm{K} 45 \mathrm{DH})$. Rehydrated yeast was then added and mixed with the rest of the ingredients for $8 \mathrm{~min}$ at speed $2.150 \mathrm{~g}$ of batter was placed into oil-coated aluminium pans $(159 \times 109 \times 39$ $\mathrm{mm}$ ) and fermented at $30{ }^{\circ} \mathrm{C}$ and $90 \% \mathrm{RH}$ for $60 \mathrm{~min}$. Subsequently, they were baked at $190{ }^{\circ} \mathrm{C}$ for $40 \mathrm{~min}$, after which they were removed from the aluminium pans and left to cool for $1 \mathrm{~h}$ at room temperature, before being packaged in polyethylene bags. The breads were stored at $24{ }^{\circ} \mathrm{C}$ until analysed, and each elaboration was performed twice. 
Table 1. Formulation of the batters.

\begin{tabular}{lllllll} 
& Control & $\mathbf{1 0 0 P}$ & $\mathbf{7 5 P / 2 5 E}$ & $\mathbf{5 0 P / 5 0 E}$ & $\mathbf{2 5 P / 7 5 E}$ & $\mathbf{1 0 0 E}$ \\
\hline Starch (g) & 100 & 70 & 70 & 70 & 70 & 70 \\
Pea protein (g) & - & 30 & 22.5 & 15 & 7.5 & - \\
Egg White protein $(\mathbf{g})$ & - & - & 7.5 & 15 & 22.5 & 30 \\
Oil (g) & 6 & 6 & 6 & 6 & 6 & 6 \\
Sugar (g) & 5 & 5 & 5 & 5 & 5 & 5 \\
Yeast (g) & 3 & 3 & 3 & 3 & 3 & 3 \\
HPMC (g) & 2 & 2 & 2 & 2 & 2 & 2 \\
Salt (g) & 1.8 & 1.8 & 1.8 & 1.8 & 1.8 & 1.8 \\
Water (g) & variable & variable & variable & variable & variable & variable \\
*Water level was changed to model its influence in the specific volume.
\end{tabular}

\subsubsection{The optimisation of the hydration levels of the breads}

The optimal hydration level (OHL) ( $\mathrm{g}$ of water/100 $\mathrm{g}$ of protein-starch) for each sample was established after elaborating the breads with at least five different hydration levels (Figure 1) and measuring their specific volumes, following the methodology of Sahagún \& Gómez (2018) with some modifications. In this case, the OHL was considered to be the hydration needed to achieve a specific volume of $5.5 \pm 0.5 \mathrm{~cm}^{3} / \mathrm{g}$. The $\mathrm{OHL}$ was calculated from the resulting equation of the modelling of each type of bread. Optimised batters (OBA) and optimised breads (OBE) were considered those that contained the amount of water needed to obtain the desired constant specific volume. The bread volumes were measured with a laser-based scanner (Volscan Profiler 300; Stable Microsystems, Surrey, UK) and conducted on six loaves from each elaboration. The bread weights were also recorded, and the specific volume was calculated as the relationship between the bread volume and its weight:

$$
\text { Specific volume }=\frac{\text { bread volume }}{\text { bread weight }}
$$

Both parameters were measured the day after baking.

\subsubsection{Rheological characteristics of the $\mathrm{OBA}$}

The rheological behaviour of the OBA without yeast was studied using a Thermo Scientific Haake RheoStress-controlled strain rheometer (Thermo Fisher Scientific, Schwerte, Germany) at $25{ }^{\circ} \mathrm{C}$, with a parallel-plate geometry (60 mm diameter titanium serrated plate-PP60 Ti). A $3 \mathrm{~mm}$ gap 
was used. The batters were placed in the rheometer and allowed to rest for $300 \mathrm{~s}$ before the analysis. A strain sweep test from 0.1 to $100 \mathrm{~Pa}$ was carried out at $1 \mathrm{~Hz}$ and from this test, the linear viscoelastic region was determined. Then, a frequency sweep test from 10 to $0.1 \mathrm{~Hz}$ was carried out at a strain value included in the linear viscoelastic region. The elastic modulus $\left(\mathrm{G}^{\prime}[\mathrm{Pa}]\right)$ and viscous modulus $\left(\mathrm{G}^{\prime \prime}[\mathrm{Pa}]\right)$ were obtained. The samples were analysed in duplicate per batch. Two batches were elaborated.

\subsubsection{Physical characteristics of $O B E$}

The weight loss of the OBE was determined using the following formula:

$$
\text { Weight loss }(\%)=\frac{\text { Batter weight }}{\text { Bread weight } 1 \text { day after baking }} * 100
$$

Crumb texture was determined using a TA-XT2 texture analyser (Stable Microsystems, Surrey, UK). A 25-mm diameter cylindrical aluminium probe was used in a "texture profile analysis" (TPA) double compression test. The experimental conditions were a penetration to $50 \%$ of the depth, a trigger force of $5 \mathrm{~g}$, a test speed of $1 \mathrm{~mm} / \mathrm{s}$, and a $10 \mathrm{~s}$ delay between the first and second compressions. From each bread batch, two breads were sliced into pieces of $20 \mathrm{~mm}$ thickness and the two central slices were used in the measurement, as in Sahagún \& Gómez (2018). Hardness $(\mathrm{N})$, springiness, cohesiveness, and chewiness were calculated. Measurements were done 1 and 5 days after baking. Samples were kept in polyethylene bags at $24{ }^{\circ} \mathrm{C}$ prior to analysis.

\subsubsection{Statistical analysis}

Data were studied using one-way analysis of variance (simple ANOVA). When significant $(p<0.05)$ differences were found, Fisher's least significant differences (LSD) test was performed to determine the differences among means. Statistical analyses were completed using Statgraphics Centurion XVI software (StatPoint Technologies Inc, Warrenton, Victoria, USA). 


\section{Results and discussion}

\subsection{Hydration optimisation}

The relationship between specific volumes and hydration levels for each bread is shown in Figure 1. As expected, and as previously reported by Sahagún \& Gómez (2018), the specific volume was influenced by both the level of hydration and the source of protein. Control formula achieved its highest maximum specific volume at around $8 \mathrm{~cm}^{3} / \mathrm{g}$, while $100 \mathrm{P}, 75 \mathrm{P} / 25 \mathrm{E}, 50 \mathrm{P} / 50 \mathrm{E}, 25 \mathrm{P} / 75 \mathrm{E}$, and $100 \mathrm{E}$ breads presented maximum specific volumes that were 27.5, 25.00, 25.00, 12.50, and $26.25 \%$, respectively, lower than the control. For our target specific volume $\left(5.5 \pm 0.5 \mathrm{~cm}^{3} / \mathrm{g}\right)$, the control needed a hydration level of $69.95 \mathrm{~g} / 100 \mathrm{~g}$ starch, while the $100 \mathrm{E}, 25 \mathrm{P} / 75 \mathrm{E}, 50 \mathrm{P} / 50 \mathrm{E}$, $75 \mathrm{P} / 25 \mathrm{E}$, and 100P breads needed hydration levels of 80.49, 70.24, 105.45, 110.85, and 139.22 $\mathrm{g} / 100 \mathrm{~g}$ starch-protein mixture, respectively. These results show that the hydration needs for our target specific volume increased progressively when the pea protein content was increased, which can be related to the higher and lower water binding capacity (WBC) of the pea and egg white proteins, respectively.

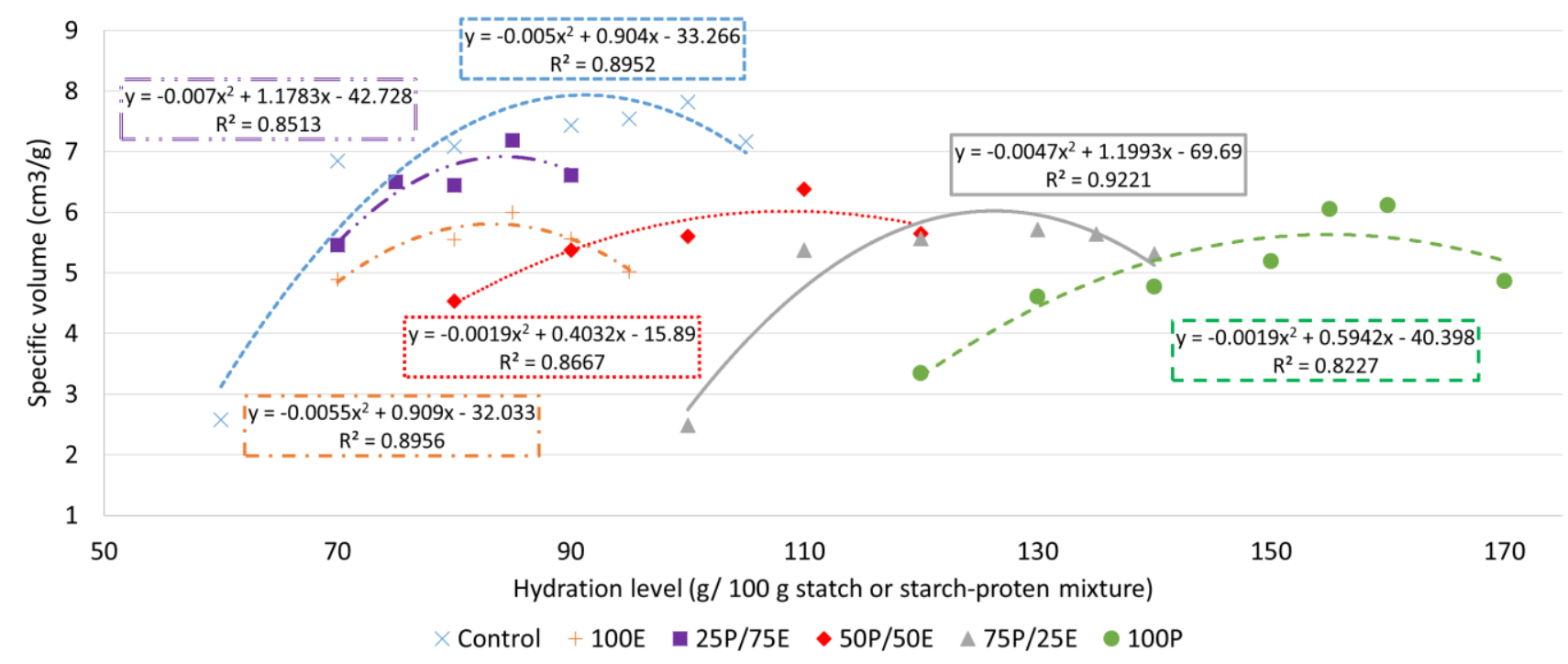

Figure 1. Influence of water content in specific volume of the gluten-free breads.

WBC is defined as the amount of water retained by the sample after it has been centrifuged and the excess water has been removed. Ingredients with lower WBC gave place to more liquid-like batters than ingredients with higher WBC. Mancebo, Martínez, Merino, de la Hera \& Gómez 
(2017) observed in gluten-free breads with hydroxyl propyl methyl cellulose that a low batter consistency, that is decreased when increasing the hydration level in the formulation, improved the final bread volume, in agreement with our results. However, batter consistency should not be excessively low. Figure 1 indicates that from a certain hydration level, different for each batter, specific volume drops, in agreement with Mancebo et al. (2017), Sahagún \& Gómez (2018), and Ziobro et al. (2016). This "limiting consistency" is the consistency at which the batter is not able to retain air bubbles during baking, and therefore a drop in volume occurs (Miś, Nawrocka, Lamorski, \& Dziki, 2018). The different "limiting consistency" for each batter, further discussed (see 3.2.), is likely to be related with the ability of each batter to entrap air in the form of air bubbles, , influenced by the foaming capacity of the ingredients. It seems logical that when batters are enriched with egg white proteins, well known for their good foaming properties (Mine, 1995), they will retain air bubbles at a lower consistency than when enriched with pea proteins. This justifies the progressively higher "limiting consistency," when increasing the pea content in our batters.

Although to achieve the target volume higher amount of water was needed when increasing the pea protein content in breads, these needs were not the weighted average of the hydration level needed to achieve the maximum specific volume of the $100 \mathrm{P}$ and $100 \mathrm{E}$ breads. In addition, it is noteworthy that $25 \mathrm{P} / 75 \mathrm{E}$ batters achieved the OHL with a hydration level lower than $100 \mathrm{E}$. This shows that interactions between egg white and pea protein are taking place, probably related with the specific effect of each protein reported before (egg white protein reduces voids of the crumb structure due to the good foaming capacity, while pea protein increments the consistency due to the high WBC). Figure 1 shows that to achieve the highest protein-enriched breads volumes, batters with a high content of egg white protein are preferred. This is probably because egg white protein coagulates at relatively low temperatures $\left(61-84{ }^{\circ} \mathrm{C}\right.$ ) (Donovan, Mapes, Davis, \& Garibaldi, 1975), and crumb structure sets at the early stages of baking, counteracting the consistency decrease that would result in breads with lower volumes. Nevertheless, a small percentage of pea protein, with high WBC, seems to help in the stabilization, making consistency decrease less likely to happen before crumb structure is set. In fact, at the same hydration level, $25 \mathrm{P} / 50 \mathrm{E}$ batters result in breads with higher volumes than those made with $100 \mathrm{E}$ batter. Therefore, to equal the volumes to our target volume, the hydration level of $25 \mathrm{P} / 50 \mathrm{E}$ batter needed to be reduced respect the hydration of 100E. Nevertheless, this stabilizing effect of pea protein only 
seems to work with high content of egg white protein, as a further increase in pea protein results in a poor crumb structure, that will be discussed latter on (see 3.3.).

\subsection{Rheological characteristics of OBA}

Rheology of OBA is shown in Figure 2. 100E and 50P/50E batters' consistency was too low and it could not be measured. Although the hydration level of $100 \mathrm{E}$ was the lowest, water-binding capacity of egg white protein is null (as shown in 2.1.), which is most probably the factor that reduces the batter consistency, as ingredients with low WBC can entrap less water and give place to batters with lower consistency (Martínez \& Gómez, 2017). Sahagún \& Gómez (2018) experienced the same problem when measuring rheology with their batter enriched with egg white protein, and they also attributed this to its low consistency, in agreement with our observations.

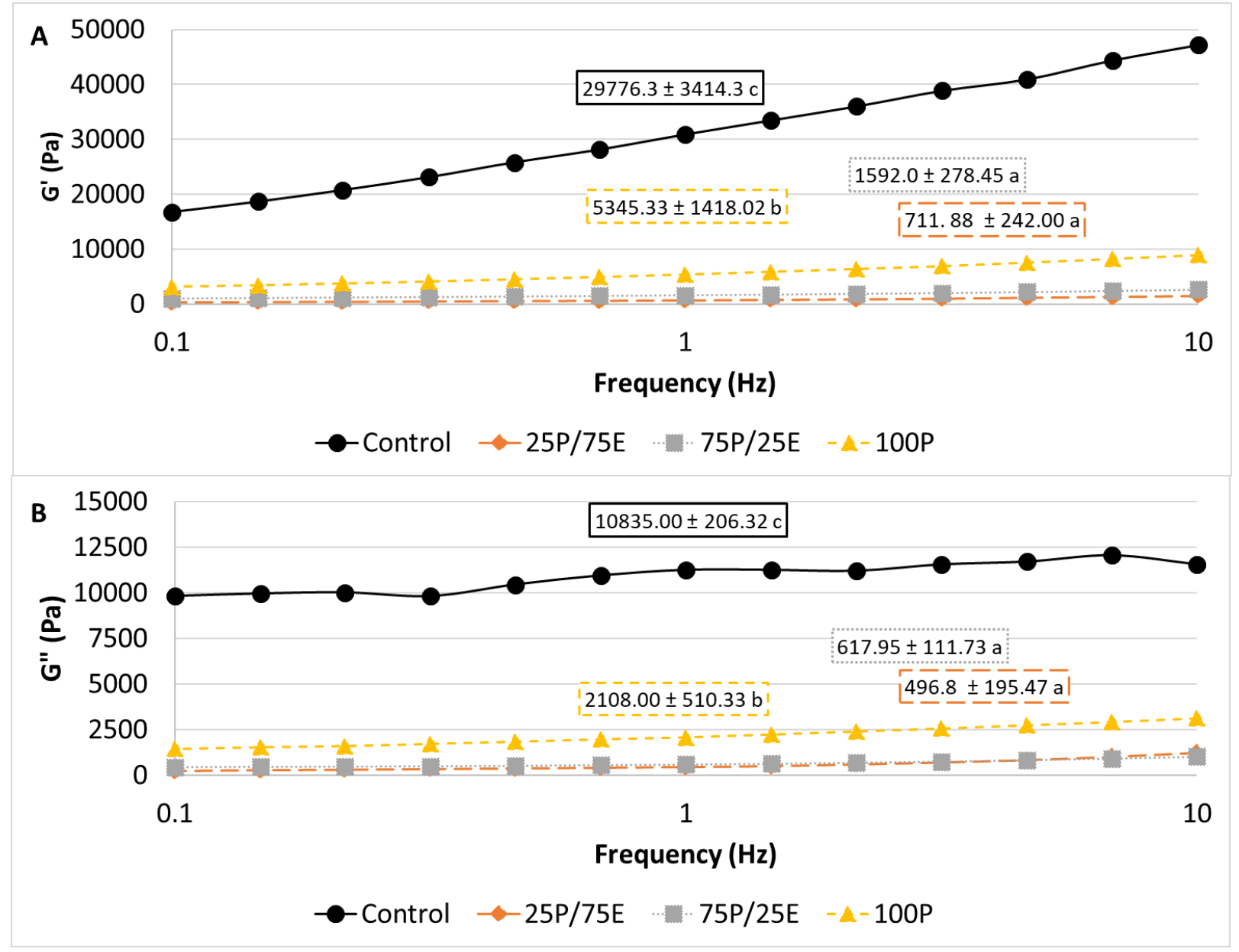

Figure 2. Dynamic oscillatory properties of the optimised batters enriched with protein( $(s)$ and control (circle: Control; triangle: 100P; square: 75P/25E; diamond: 25P/75E). $G^{\prime}$ and $G^{\prime \prime}$ values at 
frequency $1 \mathrm{~Hz}$ are also included. These values are expressed as means $\pm S D$ of duplicate assays. Samples in the same column with the same letter $(s)$ did not present significant differences $(p>0.05)$.

All the other batters presented a $\mathrm{G}^{\prime}$ higher than $\mathrm{G}^{\prime \prime}$, indicating a solid-like behaviour. Control OBA, which had one of the lowest hydration level, presented a significantly higher $\mathrm{G}^{\prime}$ and $\mathrm{G}^{\prime \prime}$ with respect to all the other samples.

For its part, the 100P OBA, which had the highest hydration level but also high water entrapment because of the high amount of pea protein (which has a high water-binding capacity), showed the highest $\mathrm{G}^{\prime}$ and $\mathrm{G}^{\prime \prime}$, after the control $\mathrm{OBA}$. $75 \mathrm{P} / 25 \mathrm{E}$ and $25 \mathrm{P} / 75 \mathrm{E}$ presented values significantly lower than 100P, without significant differences between them in terms of $\mathrm{G}^{\prime}$ and $\mathrm{G}^{\prime \prime}$. Ziobro et al. (2016) and Crockett et al. (2011) also reported a decrease of $\mathrm{G}^{\prime}$ and $\mathrm{G}^{\prime \prime}$ moduli, when albumin was added to gluten-free doughs. Despite the lack of significant differences between these two OBA, a trend was observed; when the pea protein content was decreased and the egg white protein increased, the consistency of the OBA was lower, in agreement with the trend apparent in the other samples. The fact that $25 \mathrm{P} / 75 \mathrm{E}$ was measurable but $50 \mathrm{P} / 50 \mathrm{E}$ was not may be due to the better entrapment of air bubbles by $25 \mathrm{P} / 75 \mathrm{E}$; that factor could be the responsible for the higher viscosity, due to the higher proportion of egg white protein, which has a good foaming capacity (Mine, 1995). Such better air entrapment could be the factor that compensates for the lower waterbinding capacity of the ingredients of this batter (25P/75E), compared to 50P/50E, giving this batter a measurable viscosity. In fact, better air entrapment in gluten-free bread batters with albumin has been reported by Nozawa, Ito \& Arai (2016). OBA G' was invariably more frequency-dependent than $\mathrm{G}^{\prime \prime}$. The results of this study support the observations of Ozturk \& Mert (2018), who stated that the viscoelastic behaviour of batters is driven by their water content, the water-binding capacity of their ingredients, and the capacity of the batters to entrap air. In addition, Martínez \& Gómez (2017) reported a positive correlation between the water-binding capacity of ingredients and the consistency of batters.

Regardless of which batter presents lower or higher $\mathrm{G}^{\prime}$ and $\mathrm{G}^{\prime \prime}$ values, it is important to make it clear that even with inconstant rheology among the samples, breads with constant specific volume were obtained, which shows that there are other parameters to take into consideration when developing gluten-free breads of good quality, in addition to consistency. We believe that our 
approach of unifying the specific volumes of gluten-free breads is plausible way of meeting consumer demands.

\subsection{Characteristics of OBE}

Weight loss and textural parameters of OBE are shown in Table 2. OBEs with high egg white protein content (100E and 25P/75E) showed a weight loss significantly lower than the other OBE. These results may be driven by the lower hydration levels of OBA when containing higher egg white protein content. The lower the hydration levels, the lower the available water, which is in agreement with the results of Sahagún \& Gómez (2018) and Mancebo et al. (2017). However, our control OBE did not fit this explanation, because it had the lowest hydration level, but one of the highest weight lost. This can be explained by the thickness of the crust (Figure 3); the control OBE presented the thinner crust, while the 100E OBE had the thickest.

Table 2. Textural parameters of optimized gluten-free breads

\begin{tabular}{|c|c|c|c|c|c|c|c|c|c|c|c|c|c|c|}
\hline \multirow{3}{*}{ Control } & \multicolumn{4}{|c|}{ Hardness (N) } & \multicolumn{2}{|c|}{ Springiness } & \multicolumn{4}{|c|}{ Cohesiveness } & \multicolumn{4}{|c|}{ Chewiness } \\
\hline & \multicolumn{2}{|l|}{ Day 1} & \multicolumn{2}{|l|}{ Day 5} & Day 1 & Day 5 & \multicolumn{2}{|l|}{ Day 1} & \multicolumn{2}{|l|}{ Day 5} & \multicolumn{2}{|l|}{ Day 1} & \multicolumn{2}{|l|}{ Day 5} \\
\hline & 8.98 & \pm & 16.93 & \pm & 0.96 & 0.95 & 0.47 & \pm & 0.66 & \pm & 3.91 & \pm & 10.52 & \pm \\
\hline & $1.58 \mathrm{c}$ & & $1.04 \mathrm{~b}$ & & $0.06 \mathrm{a}$ & $0.01 \mathrm{a}$ & $0.07 \mathrm{ab}$ & & $0.02 \mathrm{e}$ & & $0.23 \mathrm{~b}$ & & $0.23 \mathrm{c}$ & \\
\hline \multirow[t]{2}{*}{$100 P$} & 1.41 & \pm & 2.67 & \pm & $0.96 \pm$ & $0.92 \pm$ & 0.50 & \pm & 0.35 & \pm & 0.66 & \pm & 0.83 & \pm \\
\hline & $0.43 \mathrm{a}$ & & $0.89 \mathrm{a}$ & & $0.05 \mathrm{a}$ & $0.06 \mathrm{a}$ & $0.04 \mathrm{~b}$ & & $0.01 \mathrm{~b}$ & & $0.12 \mathrm{a}$ & & $0.2 \mathrm{a}$ & \\
\hline \multirow[t]{2}{*}{$75 \mathrm{P} / 25 \mathrm{E}$} & 4.76 & \pm & 5.79 & \pm & 0.98 & 0.97 & 0.43 & \pm & 0.30 & \pm & 1.97 & \pm & 1.68 & \pm \\
\hline & $0.23 \mathrm{~b}$ & & $0.35 \mathrm{a}$ & & $0.04 \mathrm{a}$ & $0.01 \mathrm{a}$ & $0.02 \mathrm{ab}$ & & $0.01 \mathrm{a}$ & & $0.08 \mathrm{ab}$ & & $0.17 \mathrm{ab}$ & \\
\hline \multirow[t]{2}{*}{ 50P/50E } & 9.10 & \pm & 14.81 & \pm & 0.98 & 0.95 & 0.40 & \pm & 0.33 & \pm & 3.58 & \pm & 4.59 & \pm \\
\hline & $1.55 \mathrm{c}$ & & $1.63 \mathrm{~b}$ & & $0.03 \mathrm{a}$ & $0.02 \mathrm{a}$ & $0.00 \mathrm{a}$ & & $0.01 \mathrm{ab}$ & & $0.5 \mathrm{~b}$ & & $0.24 \mathrm{~b}$ & \\
\hline \multirow[t]{2}{*}{ 25P/75E } & 27.44 & \pm & 60.03 & \pm & 0.95 & $0.96 \pm$ & 0.47 & \pm & 0.44 & \pm & 12.12 & \pm & 25.27 & \pm \\
\hline & $1.59 \mathrm{e}$ & & $0.85 \mathrm{~d}$ & & $0.02 \mathrm{a}$ & $0.01 \mathrm{a}$ & $0.04 \mathrm{ab}$ & & $0.03 \mathrm{c}$ & & $1.64 \mathrm{c}$ & & $2.34 \mathrm{~d}$ & \\
\hline \multirow[t]{2}{*}{$100 E$} & 21.98 & \pm & 44.17 & \pm & 1.03 & $0.94 \pm$ & 0.61 & \pm & 0.54 & \pm & 13.83 & \pm & 22.39 & \pm \\
\hline & $1.87 \mathrm{~d}$ & & $3.27 \mathrm{c}$ & & $0.01 \mathrm{a}$ & $0.03 \mathrm{a}$ & $0.01 \mathrm{c}$ & & $0.00 \mathrm{~d}$ & & $1.31 \mathrm{c}$ & & $2.57 \mathrm{~d}$ & \\
\hline
\end{tabular}

*Data are expressed as means $\pm S D$ of duplicate assays. Samples in the same column with the same letter $(s)$ did not present significant differences ( $p>0.05$ ).

With regard to the textural parameters, the literature usually finds a correlation between hardness and specific volume (Jafari, Koocheki, \& Milani, 2018; Mancebo et al., 2017; Martínez \& Gómez, 2017). Since in this study the specific volume of all samples its constant, this theory cannot be applied to our results. The significant differences observed between our samples with a unified 
specific volume proves that hardness is influenced by other factors in addition to the specific volume, as suggested by Krupa-Kozak et al. (2013).

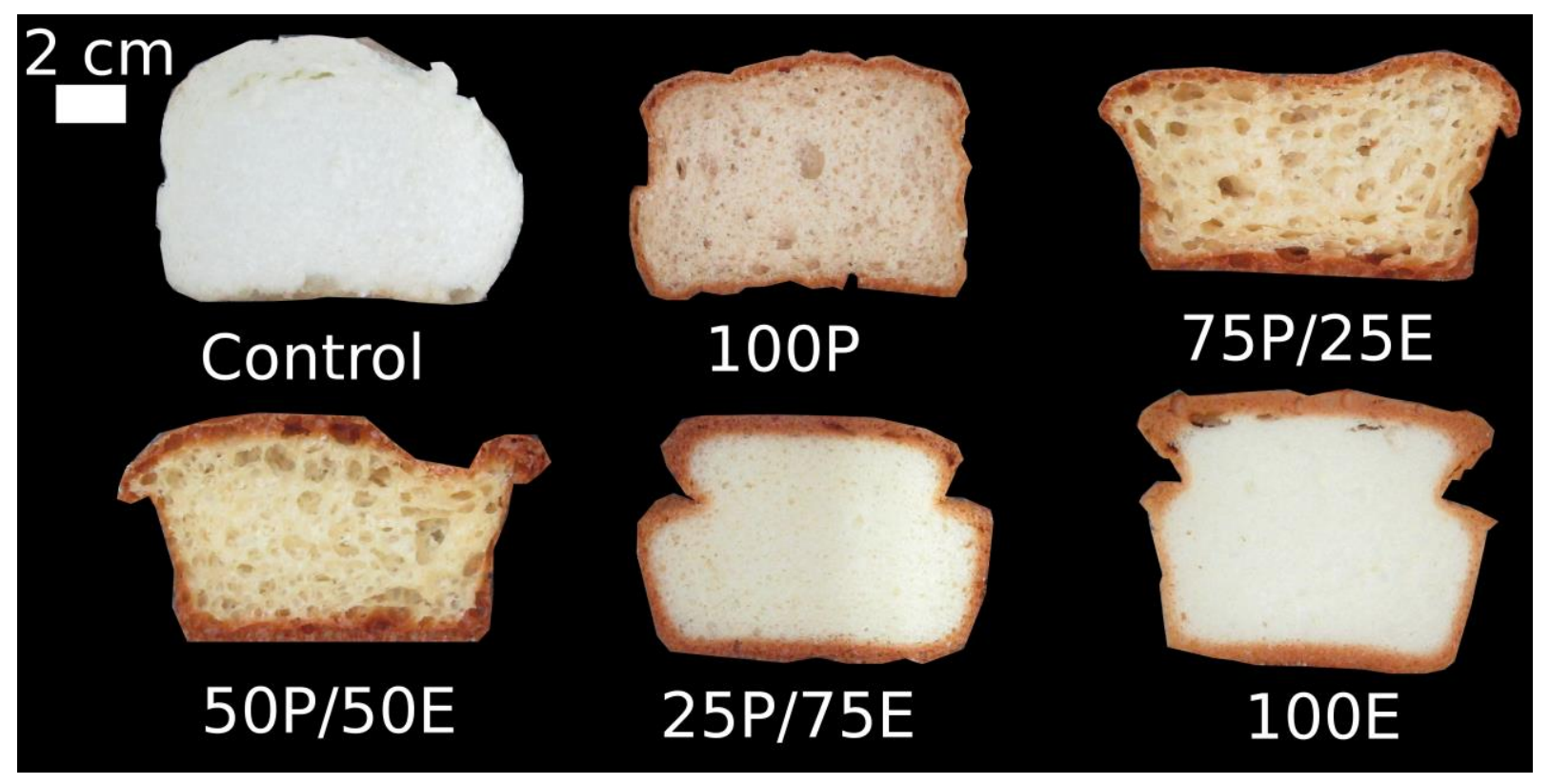

Figure 3. Pictures of the gluten-free breads.

It was observed that breads with a higher pea protein content $(100 \mathrm{P}$ and $75 \mathrm{P} / 25 \mathrm{E})$ showed a significantly lower hardness than the control, while breads with a higher egg white protein content $(100 \mathrm{E}$ and $25 \mathrm{P} / 75 \mathrm{E})$ revealed the opposite effect, increasing hardness values. Bread that had the same amount of pea and egg white proteins 50P/50E showed no significant differences to the control. These differences could be attributed to the good coagulation properties of egg white protein at a relatively low temperature, similar to the temperature required for starch gelatinisation (Biliaderis, Maurice, \& Vose, 1980), as shown by Bravo-Núñez \& Gómez (Bravo-Núñez \& Gómez, 2019). In addition, the good foaming capacity of egg white proteins (Mine, 1995) may be a driving factor that boosted the hardness values of $100 \mathrm{E}$ and $25 \mathrm{P} / 75 \mathrm{E}$, because it allows for the better retention of air inside the breads (Figure 4), which will result in a higher resistance to penetration (Mills, Wilde, Salt, \& Skeggs, 2003). Nevertheless, Han et al. (2019) did not find any differences between the control and up to $15 \%$ egg white protein-enriched breads. The differences between the findings of Han et al. (2019) and this study may be due to differences in the used ingredients (they use a commercial gluten-free flour and a different control formulation), the protein percentage, and their inconstant specific volume, again showing the importance of unifying specific volumes of gluten-free breads. Storage has been found to increase staling (and 
therefore crumb hardness) (Fadda, Sanguinetti, Del Caro, Collar, \& Piga, 2014) due to moisture loss, starch retrogradation, and interactions between bread constituents. The control bread showed a hardening that was more evident than the OBEs with a high content of pea protein (100P, 75P/25E, and 50P/50E). Similarly to these results, Korus, Witczak, Ziobro \& Juszczak (2015) showed that the crumbs of starch breads hardened faster than those of wheat breads (containing gluten protein). When the egg white content in the OBE was increased (25P/75E and 100E), the degree of hardening was found to be higher than for the others OBE. All the OBE showed an inverse correlation between initial hardness (day 0) and the hardening effect, in agreement with Sahagún \& Gómez (2018). The differences between OBEs containing more than one protein than the other can be attributed to the differences in the hydration of the doughs and WBC of the proteins. A high WBC of pea protein, together with the higher hydration level of doughs, when higher the ratio of pea protein, may help to retain water during storage. The findings of Han et al. (2019) contradict these results; they found that the hardening of gluten-free breads enriched with egg white proteins was lower than their control, but again, this could be due to the adjustments to hydration levels made in the course of this research.

With regard to the rest of the measured textural parameters, springiness was not affected by any of the protein enrichments, nor by the aging time. On day 1, cohesiveness was only enhanced by 100E, in agreement with Sahagún \& Gómez (2018). Nevertheless, after 5 days of storage, all the enriched breads showed significantly lower cohesiveness than the control, and a decrease with respect to day 1, while the control presented a higher cohesiveness after 5 days of storage. This may indicate that starch helps to maintain the cohesiveness of batters. Increasing the pea protein ratio resulted in a decrease in chewiness, while the increase in egg white protein had the opposite effect. Bread that contained the same amount of both proteins $(50 \mathrm{P} / 50 \mathrm{E})$ showed similar values to the control.

The internal structure of the crumbs is shown in Figure 4. The uniform structure of breads with a higher amount of egg white protein (100 E and 25P/75E) is likely to be due to the good foaming capacity (Mine, 1995) and relatively low denaturing temperature of egg white protein $\left(61-84{ }^{\circ} \mathrm{C}\right)$ (Donovan et al., 1975). This good foaming capacity means that very small bubbles are entrapped in the batter during the mixing and do not undergo coalescence during fermentation. When baking, a "low" denaturing temperature implies that denaturisation is taking place in the early stages of 
this process and after this denaturalisation, disulphide bridges form between albumen molecules and lead to the formation of a very strong and elastic gel network structure (Kiosseoglou \& Paraskevopoulou, 2006).

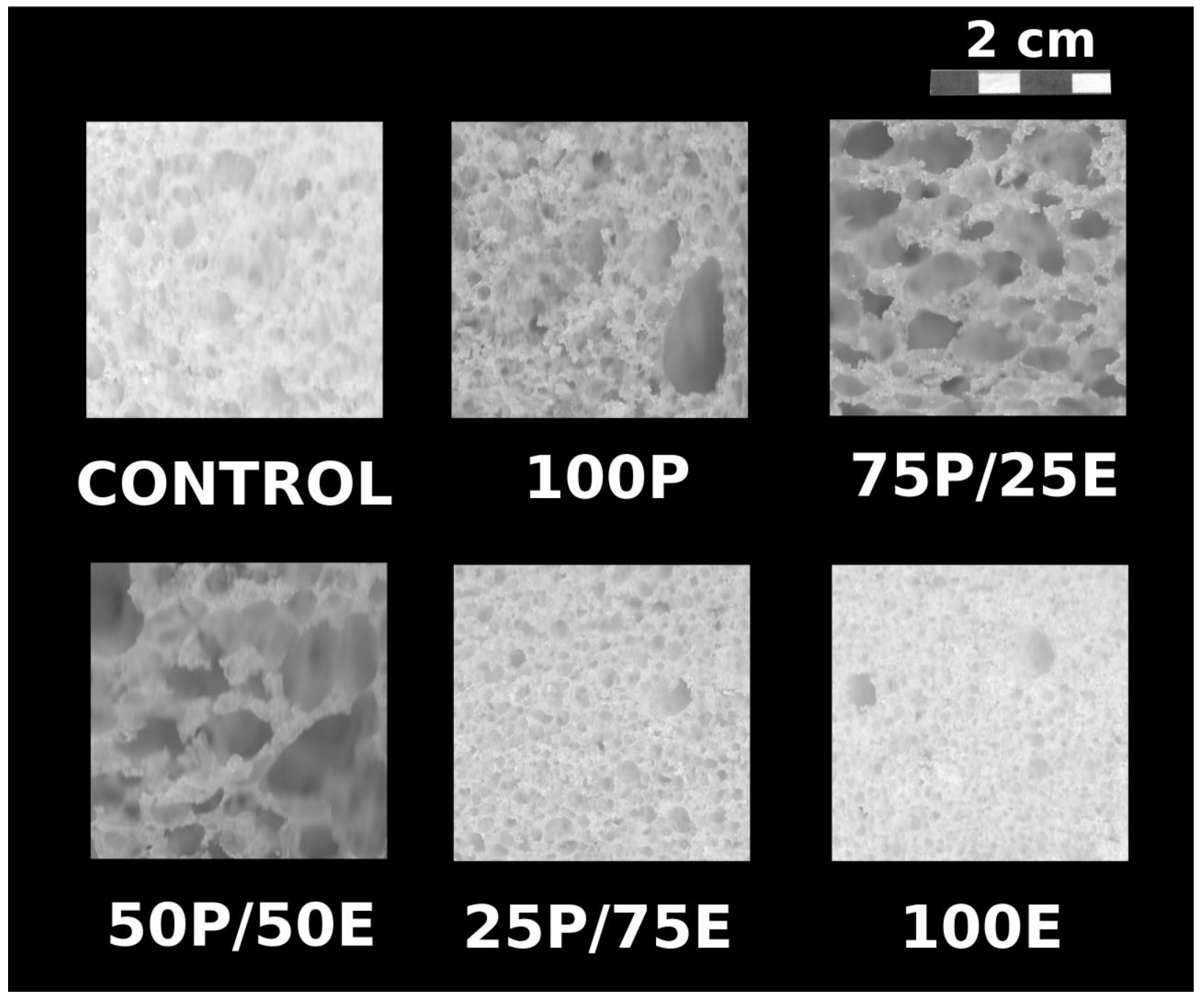

Figure 4. Scanner images of the gluten-free bread crumbs.

Due to a high amount of air entrapped in the batter and the formation of a new elastic and resistant gel network, this air is not able to escape or break the network, giving rise to a uniform structure composed of small gas cells. Han et al. (2019) also obtained a more uniform and closed structure ,when increasing the egg white protein content. The air cells of $25 \mathrm{P} / 75 \mathrm{E}$ seemed slightly bigger than those of $100 \mathrm{E}$, probably due to the presence of pea protein, and consequently lower amount of egg white protein in $25 \mathrm{P} / 75 \mathrm{E}$ bread. The $100 \mathrm{P}$ bread presented a heterogenic and more open air-cell distribution, with some big and some small ones interconnected with each other, probably 
due to coalescence phenomena occurring during both the fermentation and baking stages, resulting in an opening of the bread crumb structure. This is likely to be due to the bad emulsifying properties of pea protein. For their part, $75 \mathrm{P} / 25 \mathrm{E}$ and $50 \mathrm{P} / 50 \mathrm{E}$ showed a similar internal cell distribution, with a relatively homogenous distribution of big cells, separated from each other by relatively wide "walls", with small air cells inside. This effect is more obvious in the 50P/50E breads.

\section{Conclusion}

An examination of the influence of hydration levels on the specific volume of gluten-free breads allows the identification of the right level of hydration needed for a target specific volume. This is a novel approach, in contrast with the widely use "constant consistency" method, suitable for wheat-based breads, but not for gluten-free ones.

For our target volume of $5 \pm 0.5 \mathrm{~cm}^{3} / \mathrm{g}$, hydration needs increased when increasing pea protein content. Batter consistency was found to be mainly influenced by the hydration level, the ability of the batter to entrap air, and the water-binding capacity of their components. The lower hydration levels of batters containing ingredients with high water-binding capacity can result in higher $\mathrm{G}^{\prime}$ and $\mathrm{G}^{\prime \prime}$ values than batters with higher hydration levels and ingredients with a lower water-binding capacity. The hardness increased when the proportion of egg white protein was increased, and decreased when the proportion of pea protein was increased, while bread with the same amount of both proteins presented no significant differences from the control. Of all the gluten-free breads studied, it seems that the bread with the same amount of both proteins presented similar characteristics with respect to the control.

\section{Acknowledgments}

The authors acknowledge the financial support of the Spanish Ministry of Economy and Competitiveness (Project AGL2014-52928-C2) and the European Regional Development Fund (FEDER). Authors are thankful to Thais Sader de Melo for her support in the laboratory. Ángela Bravo-Núñez and Marta Sahagún would like to thank the University of Valladolid for their predoctoral fellowships. 


\section{Bibliography}

AACC. (2012). Approved methods of the American Association of Cereal Chemists (11th ed.). St. Paul, Minnesota: American Association of Cereal Chemists.

Beelen, J., Vasse, E., Janssen, N., Janse, A., de Roos, N. M., \& de Groot, L. C. P. G. M. (2018). Proteinenriched familiar foods and drinks improve protein intake of hospitalized older patients: A randomized controlled trial. Clinical Nutrition, 37(4), 1186-1192. https://doi.org/10.1016/j.clnu.2017.05.010

Biliaderis, C. G., Maurice, T. J., \& Vose, J. R. (1980). Starch gelatinization phenomena studied by differential scanning calorimetry. Journal of Food Science, 45(6), 1669-1674. https://doi.org/10.1111/j.1365-2621.1980.tb07586.x

Bravo-Núñez, Á., \& Gómez, M. (2019). Physicochemical properties of native and extruded maize flours in the presence of animal proteins. Journal of Food Engineering, 243, 49-56. https://doi.org/10.1016/j.jfoodeng.2018.09.005

Crockett, R., Ie, P., \& Vodovotz, Y. (2011). Effects of soy protein isolate and egg white solids on the physicochemical properties of gluten-free bread. Food Chemistry, 129(1), 84-91. https://doi.org/10.1016/j.foodchem.2011.04.030

Donovan, W. J., Mapes, C. J., Davis, J. G., \& Garibaldi, J. A. (1975). A differential scanning calorimetric study of the stability of egg white to heat denaturation. Journal of the Science of Food and Agriculture, 26(1), 73-83. https://doi.org/10.1002/jsfa.2740260109

Espinosa-Ramírez, J., Garzon, R., Serna-Saldivar, S. O., \& Rosell, C. M. (2018). Mimicking gluten functionality with $\beta$-conglycinin concentrate: Evaluation in gluten free yeast-leavened breads. Food Research International, 106, 64-70. https://doi.org/10.1016/j.foodres.2017.12.055

Fadda, C., Sanguinetti, A. M., Del Caro, A., Collar, C., \& Piga, A. (2014). Bread staling: Updating the view. Comprehensive Reviews in Food Science and Food Safety, 13(4), 473-492. https://doi.org/10.1111/1541-4337.12064

Han, A., Romero, H. M., Nishijima, N., Ichimura, T., Handa, A., Xu, C., \& Zhang, Y. (2019). Effect of egg white solids on the rheological properties and bread making performance of gluten-free batter. Food Hydrocolloids, 87(June 2018), 287-296. https://doi.org/10.1016/j.foodhyd.2018.08.022

Jafari, M., Koocheki, A., \& Milani, E. (2018). Functional effects of xanthan gum on quality attributes and microstructure of extruded sorghum-wheat composite dough and bread. LWT-Food Science and Technology, 89, 551-558. https://doi.org/10.1016/j.lwt.2017.11.031

Kiosseoglou, V., \& Paraskevopoulou, A. (2006). Eggs. In Bakery Products: Science and Technology (pp. 161-172). Ames, Iowa, USA: Blackwell Publishing. https://doi.org/10.1002/9780470277553.ch8 
Korus, J., Witczak, M., Ziobro, R., \& Juszczak, L. (2015). The influence of acorn flour on rheological properties of gluten-free dough and physical characteristics of the bread. European Food Research and Technology, 240(6), 1135-1143. https://doi.org/10.1007/s00217-015-2417-y

Krupa-Kozak, U., Baczek, N., \& Rosell, C. M. (2013). Application of dairy proteins as technological and nutritional improvers of calcium-supplemented gluten-free bread. Nutrients, 5(11), 4503-4520. https://doi.org/10.3390/nu5114503

Mancebo, C. M., Martínez, M. M., Merino, C., de la Hera, E., \& Gómez, M. (2017). Effect of oil and shortening in rice bread quality: Relationship between dough rheology and quality characteristics. Journal of Texture Studies, 48(6), 597-606. https://doi.org/10.1111/jtxs.12270

Martínez, M. M., \& Gómez, M. (2017). Rheological and microstructural evolution of the most common gluten-free flours and starches during bread fermentation and baking. Journal of Food Engineering, 197, 78-86. https://doi.org/10.1016/j.jfoodeng.2016.11.008

Martínez, M. M., Oliete, B., Román, L., \& Gómez, M. (2014). Influence of the addition of extruded flours on rice bread quality. Journal of Food Quality, 37(2), 83-94. https://doi.org/10.1111/jfq.12071

Mills, E. N. C., Wilde, P. J., Salt, L. J., \& Skeggs, P. (2003). Bubble formation and stabilization in bread dough. Food and Bioproducts Processing, 81(3), 189-193. https://doi.org/http://dx.doi.org/10.1205/096030803322437956

Mine, Y. (1995). Recent advances in the understanding of egg white functionality. Trends in Food Science \& Technology, 6, 225-232.

Miranda, J., Lasa, A., Bustamante, M. A., Churruca, I., \& Simon, E. (2014). Nutritional differences between a gluten-free diet and a diet containing equivalent products with gluten. Plant Foods for Human Nutrition, 69(2), 182-187. https://doi.org/10.1007/s11130-014-0410-4

Miś, A., Nawrocka, A., Lamorski, K., \& Dziki, D. (2018). Dynamics of gas cell coalescence during baking expansion of leavened dough. Food Research International, 103, 30-39. https://doi.org/10.1016/j.foodres.2017.10.019

Nieuwenhuizen, W. F., Weenen, H., Rigby, P., \& Hetherington, M. M. (2010). Older adults and patients in need of nutritional support: Review of current treatment options and factors influencing nutritional intake. Clinical Nutrition, 29(2), 160-169. https://doi.org/10.1016/j.clnu.2009.09.003

Nowson, C., \& O'Connell, S. (2015). Protein requirements and recommendations for older people: A review. Nutrients, 7(8), 6874-6899. https://doi.org/10.3390/nu7085311

Nozawa, M., Ito, S., \& Arai, E. (2016). Effect of ovalbumin on the quality of gluten-free rice flour bread made with soymilk. LWT - Food Science and Technology, 66, 598-605. https://doi.org/10.1016/j.lwt.2015.11.010 
Ozturk, O. K., \& Mert, B. (2018). The effects of microfluidization on rheological and textural properties of gluten-free corn breads. Food Research International, 105(August 2017), 782-792. https://doi.org/10.1016/j.foodres.2017.12.008

Ronda, F., Perez-Quirce, S., Lazaridou, A., \& Biliaderis, C. G. (2015). Effect of barley and oat $\beta$-glucan concentrates on gluten-free rice-based doughs and bread characteristics. Food Hydrocolloids, 48, 197-207. https://doi.org/10.1016/j.foodhyd.2015.02.031

Sahagún, M., \& Gómez, M. (2018). Assessing influence of protein source on characteristics of glutenfree breads optimising their hydration level. Food and Bioprocess Technology, 11(9), 1686-1694. https://doi.org/10.1007/s11947-018-2135-0

Thomas, T., Erdman, K. A., \& Burke, L. M. (2016). Nutrition and athletic performance. Medicine \& Science in Sports \& Exercise, 48(3), 543-568. https://doi.org/10.1249/MSS.0000000000000852

Ziobro, R., Juszczak, L., Witczak, M., \& Korus, J. (2016). Non-gluten proteins as structure forming agents in gluten free bread. Journal of Food Science and Technology, 53(1), 571-580.

https://doi.org/10.1007/s13197-015-2043-5 